\title{
Serum selenium concentrations in rheumatoid arthritis
}

\author{
James R O'Dell, Susan Lemley-Gillespie, William R Palmer, Arthur L Weaver, \\ Gerald F Moore, Lynell W Klassen
}

\begin{abstract}
Selenium is a trace element and an essential part of the enzyme glutathione peroxidase, which protects cells from oxidative damage. Selenium has been shown to have antiproliferative, anti-inflammatory, antiviral, and immune altering effects. Serum selenium concentrations in 101 patients with seropositive rheumatoid arthritis were found to be significantly lower than those in 29 normal, healthy controls (mean (SD) 148 (42) $v 160(25) \mu \mathrm{g} / \mathrm{l}$ ) and also lower than those in eight patients with fibrositis (148 (42) $v 166(25) \mu g / 1)$. It is speculated that serum selenium concentrations may modulate the effect of viral or other infections in subjects with the appropriate genetic background and in this way enhance the development or progression of rheumatoid arthritis.
\end{abstract}

Selenium is a trace element and an essential nutrient. ${ }^{1-4}$ The biological importance of selenium is incompletely understood, but it is an essential part of the enzyme glutathione peroxidase ${ }^{4}$ which protects cells from oxidative damage. Additionally, a large number of studies have now shown an inverse relation between serum selenium concentrations and the incidence of cancer. ${ }^{5-8}$ Furthermore, selenium has been shown to have antiproliferative, ${ }^{9-12}$ antiinflammatory, ${ }^{13}$ antiviral, ${ }^{14} 15$ and immune altering effects.

The pathogenesis of rheumatoid arthritis is not completely understood but, clearly, synovial proliferation and inflammation play a central part in disease expression. Therefore the antiproliferative, anti-inflammatory, and immune modulating effects of selenium are of interest. A number of studies have shown that serum selenium concentrations are lower in patients with rheumatoid arthritis than in controls. ${ }^{1617}$ These studies were reported from areas of relatively low selenium intakes, however. We report here the serum selenium concentrations in a large number of patients with a variety of rheumatic diseases in an area where selenium intakes are relatively high.

\section{Patients and methods} PATIENTS

Serum samples were collected from 101 patients with seropositive rheumatoid arthritis, 21 patients with seronegative rheumatoid arthritis, 49 patients with osteoarthritis, 20 patients with systemic lupus erythematosus, eight with fibrositis, and 29 controls (healthy volunteers with- out evidence of rheumatic disease). Additionally, as another control population serum samples from 19 patients with pancreatic carcinoma were collected. This control group was included because many previous reports have described low selenium concentrations in such a group. Table 1 presents the results.

\section{METHODS}

Serum samples from patients seen in the rheumatological clinic at the University of Nebraska Medical Center and affiliated clinics were collected and a questionnaire about the patient's diagnosis, treatment, and relevant laboratory tests was completed by the participating doctors. Patients with rheumatoid arthritis fulfilled at least four of the new American College of Rheumatology criteria ${ }^{18}$ for the diagnosis of rheumatoid arthritis. The activity of rheumatoid disease was scored on a scale from zero to four for patients followed up at the University of Nebraska Medical Center $(0=$ no activity, $1=$ trace, $2=$ mild, $3=$ moderate, and $4=$ severe activity). Data on the activity of disease were available for 29 patients with seropositive rheumatoid arthritis (table 2). All patients with a disease activity score of 2 or greater were considered to have active disease.

Serum samples were frozen at $-34^{\circ} \mathrm{C}$ until used. Selenium concentrations were determined by neutron activation analysis. ${ }^{19}$ Briefly, all serum samples were lyophilised and placed in clear polystyrene sample tubes with polyethylene caps. Samples were then irradiated for 20 seconds in the Omaha Veterans Administration Medical Center TRIGA nuclear reactor by means of a pneumatic transfer tube. All irradiated samples were allowed to decay for 20 seconds and then counted for a live time of 20 seconds in a closed end coaxial well GE detector. Results were reported as micrograms of selenium per litre of serum.

\section{STATISTICS}

Statistical analyses were made with Scheffe's method of multiple comparisons for the seven groups shown in table 1 and for the three groups in table 2 .

\section{Results}

Strikingly low serum selenium concentrations were found in patients with pancreatic carcinoma (table 1), which were significantly lower than concentrations found in all other groups $(p<0.01$ in all cases). As previously reported by others, 
Table 1 Serum selenium concentrations $(\mu g / l)$

\begin{tabular}{lcll}
\hline Subjects & $\begin{array}{l}\text { Number of } \\
\text { patients }\end{array}$ & $\begin{array}{l}\text { Mean age } \\
\text { (years) }\end{array}$ & $\begin{array}{l}\text { Selenium } \\
\text { mean }(S D)\end{array}$ \\
\hline Controls & 29 & $38 \cdot 9$ & $160(25)$ \\
Seropositive rheumatoid arthritis & 101 & $55 \cdot 5$ & $148(42)$ \\
Seronegative rheumatoid arthritis & 21 & $49 \cdot 9$ & $151(27)$ \\
Osteoarthritis & 49 & $62 \cdot 3$ & $143(23)$ \\
Systemic lupus erythematosus & 20 & $36 \cdot 8$ & $156(34)$ \\
Fibrositis & 8 & $54 \cdot 4$ & $166(25)$ \\
Pancreatic carcinoma & 19 & $65 \cdot 0$ & $111(38)$ \\
\hline
\end{tabular}

Table 2 Selenium concentrations in seropositive rheumatoid arthritis $(\mu g / l)$

\begin{tabular}{|c|c|c|c|}
\hline & $\begin{array}{l}\text { Number } \\
\text { of } \\
\text { patients }\end{array}$ & $\begin{array}{l}\text { Selenium } \\
\text { mean } \\
(S D)\end{array}$ & $\begin{array}{l}p \text { Value } \\
\text { (95\% confidence } \\
\text { intervals for } \\
\text { differences) }\end{array}$ \\
\hline $\begin{array}{l}\text { Active } \\
\text { Quiescent }\end{array}$ & $\begin{array}{l}13 \\
16\end{array}$ & $\begin{array}{l}129(33) \\
141(25)\end{array}$ & $<0.07(-31.0$ to 7.0$)$ \\
\hline \multicolumn{4}{|c|}{ Duration (years) } \\
\hline $\begin{array}{l}\geqslant 10 \\
\leqslant 5\end{array}$ & $\begin{array}{l}21 \\
20\end{array}$ & $\begin{array}{l}141(44) \\
138(23)\end{array}$ & NS $(-17 \cdot 5$ to $23 \cdot 5)$ \\
\hline \multicolumn{4}{|c|}{ Prednisone (mg) } \\
\hline $\begin{array}{l}5-10 \\
\text { None }\end{array}$ & $\begin{array}{l}26 \\
31\end{array}$ & $\begin{array}{l}146(27) \\
148(35)\end{array}$ & NS $(-15 \cdot 8$ to $11 \cdot 8)$ \\
\hline
\end{tabular}

we also found lower serum selenium concentrations in patients with seropositive rheumatoid arthritis than in healthy controls without rheumatic disease $(p=0.05)$. This difference remained significant when a smaller group of subjects matched for age without rheumatic disease were used as controls (data not shown, $\mathrm{p}<0.05$ ) and, furthermore, serum selenium concentrations did not change with age in our control group. Additional control groups included patients with osteoarthritis, fibrositis, seronegative rheumatoid arthritis, and patients with systemic lupus erythematosus. Although serum selenium concentrations in patients with seropositive rheumatoid arthritis were lower than those in fibrositic patients, those with seronegative rheumatoid arthritis, and patients with systemic lupus erythematosus (table 1), these differences approached significance for the fibrositic patients only $(p<0.08)$. Interestingly, serum selenium concentrations in patients with osteoarthritis were even lower than those in patients with seropositive rheumatoid arthritis and significantly lower than those in fibrositic patients $(p<0.05)$ and controls $(\mathrm{p}<0.04)$.

Table 2 shows the relation between serum selenium concentrations and activity of disease, disease duration, and the use of steroid treatment in patients with seropositive rheumatoid arthritis. Selenium concentrations were lower in patients with active disease than in those with quiescent disease. This difference approached, but did not reach, significance at the $p<0.05$ level. In our study serum selenium concentrations were not affected by disease duration nor by prednisone treatment.

\section{Discussion}

In this study we confirmed that serum selenium concentrations in patients with seropositive rheumatoid arthritis are lower than in controls without rheumatic disease and patients with fibrositis. This difference was still present when a smaller group of controls matched for age was compared with patients with rheumatoid arthritis. Furthermore, this difference in serum selenium concentrations between patients with rheumatoid arthritis and osteoarthritis and controls did not seem to be due to non-steroidal anti-inflammatory drug treatment as use of these drugs was similar in all three groups. Our findings are in agreement with most other studies previously published. ${ }^{16}{ }^{17}$ Some, however, have reported normal serum selenium concentrations in patients with rheumatoid arthritis not receiving steroids, ${ }^{20}$ and others have reported normal glutathione peroxidase activity (which usually correlates well with serum selenium concentrations) in the serum of patients with rheumatoid arthritis. ${ }^{21}$ Our study differs from previous studies in that we considered larger numbers of patients and included controls with and without rheumatic disease. Additionally, our patients came from an area of relatively high selenium intake and those previously reported were from areas of low selenium intake. We found a negative correlation between selenium concentrations and activity of disease in rheumatoid patients, as has been previously reported by others. ${ }^{17}$ Disease duration has previously been reported to have a negative correlation with selenium concentrations, ${ }^{17}$ but we found no effect of disease duration. Additionally, we found no effect of steroid treatment on selenium concentrations, possibly because our patients were receiving low doses (5-10 mg of prednisone a day) compared with those previously reported $(20-40 \mathrm{mg} / \text { day })^{20}$ to decrease selenium concentrations.

Although the weight of evidence suggests that a relative selenium deficiency is seen in patients with rheumatoid arthritis, it is unclear whether this deficiency has a role in the pathogenesis of rheumatoid arthritis or whether it is merely a consequence of the disease or its treatment. Several factors argue against a role for selenium in the pathogenesis of rheumatoid arthritis-for example, the prevalence of rheumatoid arthritis is similar in areas of high or low selenium intake 22 and patients with rheumatoid arthritis fail to respond to selenium supplementation in controlled studies. ${ }^{25} 26$ Additionally, if selenium deficiency is important in the pathogenesis of rheumatoid arthritis it is difficult to explain the low concentrations of selenium in patients with osteoarthritis reported here unless selenium deficiency is a risk factor for joint damage in general. Despite these facts the possibility of a role for selenium deficiency in the pathogenesis of rheumatoid arthritis remains intriguing in light of the number of diverse effects of selenium-namely, its anticancer, antiproliferative, anti-inflammatory, antiviral, and immunomodulatory properties.

Experimental modification of dietary selenium intake has been shown to alter disease expression in models of autoimmune and inflammatory arthritis. We have shown the profound antiproliferative effects of selenium on lymphocytes in vitro, ${ }^{910}$ and others have shown in vivo antiproliferative effects of selenium as well. ${ }^{11}$ We have also reported the protective effects of selenium supplementation on NZB/NZW female mice. ${ }^{26}$ The survival of these mice, who normally die at 9 months from an immune complex glomerulonephritis, is significantly 
improved by selenium supplementation, but the production of autoantibodies by these mice does not seem to be affected. Additionally, it has been shown that adjuvant arthritis is enhanced by selenium deficiency in rats. ${ }^{27}$ Furthermore, Kashin-Beck syndrome (big joint disease), which is characterised by inflammation, swelling, and degenerative changes of joints, is endemic in certain selenium deficient areas of China and may be prevented by selenium supplementation. ${ }^{28}$

A large number of retrospective studies and several prospective studies ${ }^{78}$ have shown a negative correlation between serum selenium concentrations and the incidence of cancer. This apparent anticancer effect of selenium has also been shown in a large number of animal studies. 56 29-31 The mechanism by which selenium exerts this anticancer effect is not completely clear, but selenium supplementation of mice or rats has been shown to boost natural killer cell activity significantly, ${ }^{9}$ and we have shown that selenium supplementation of mice augments specific antitumour responses in vivo (Petrie H T, Klassen L W, Klassen P S, Kay H D, unpublished data).

Antiviral effects of selenium have also been postulated. In vivo animal studies have shown improved antiviral responses in animals supplemented with selenium, ${ }^{15}$ and direct viral reproduction has been shown to be inhibited by selenium supplementation in mice. ${ }^{14}$ Furthermore, Keshan disease, a cardiomyopathy that is endemic to selenium deficient areas of China, is almost completely prevented by selenium supplementation. ${ }^{32}$ The pathogenesis of Keshan disease is not completely understood, but it seems that both a coxsackie-like viral infection and selenium deficiency may be required for the development of this cardiomyopathy. 5

Many different infectious agents have been suspected to assist the development of rheumatoid arthritis. The specific pathogenesis of rheumatoid arthritis is almost certainly multifactorial and may well include altered immune mechanisms, genetically determined disease susceptibility, and common environmental exposures. It is intriguing to speculate that selenium concentrations might modulate the effects of viral or other types of infections in subjects with the appropriate genetic background. Thus selenium deficiency might enhance the development or progression of rheumatoid arthritis.

Previous studies of selenium supplementation in rheumatoid arthritis have not shown a beneficial effect, but selenium treatment was given to patients with well established rheumatoid arthritis and for quite short periods of time (six months or less). A well controlled, randomised study of long term selenium supplementation given early in the course of seropositive rheumatoid arthritis might help to answer some of the questions raised.

1 Schwarz $\mathrm{K}$, Foltz C M. Selenium as an integral part of factor 3 against dietary necrotic liver degeneration. Foumal of the American Chemical Society 1957; 79: 3292-3.

2 Patterson E L, Milstrey R, Stoksfad E L R. Effect of selenium in preventing exudative diathesis in chicks. Proc selenium in preventing exudative diathesi
Soc Exp Biol Med 1957; 95: 617-20.
3 Schwarz K, Bieri J G, Briggs G M, Scott M L. Prevention of exudative diathesis in chicks by factor 3 and selenium. Proc Soc Exp Biol Med 1957; 95: 621-5.

4 Rotruck J T, Pope A L, Ganther H F, Swanson A B, Hafeman D G, Hoekstra W G. Selenium: biochemical role as a component of glutathione peroxidase. Science 1973; 179: $588-90$.

5 Schrauzer G N. Selenium in nutritional cancer prophylaxis: an update. In: Prasad K N, ed. Vitamins, nutrition and cancer. Basel: Karger, 1984: 240-50.

6 Helzlsouer K J. Selenium and cancer prevention. Semin Oncol 1983; 10: 305-10.

7 Willett W C, Morris J S, Pressel S, et al. Prediagnostic serum selenium and risk of cancer. Lancet 1983; ii: $130-4$

8 Salonen J T, Salonen R, Lappetelainen R, Maenpaa P H Alfthan G, Puska P. Risk of cancer in relation to serum concentrations of selenium and vitamins $A$ and $E$ : matched case-control analysis of prospective data. $B M \mathcal{F} 1985 ; 290$ : 417-20.

9 O'Dell J R, Lemley-Gillespie S, Kay H D, Klassen L W. The mechanism of inhibition of in vitro mitogenesis by selenium Clin Res 1987; 35: 855A.

10 Petrie H T, Tempero M A, Klassen L W, Kay H D. In vitro regulation of human lymphocyte proliferation by selenium. Biological and Trace Elements Research 1986; 11 : 127.

11 Leboeuf R A, Laishes B A, Hoekstra W G. Effects of selenium on cell proliferation in rat liver and mammalian cells as indicated by cytokinetic and biochemistry analysis. Cancer Res 1985; 45: 5496-504.

12 Medina D, Morrison D, Oborn C J. Selenium retention and inhibition of cell growth in mouse mammary epithelial cell lines in vitro. Biological and Trace Elements Research 1985; 8: $19-35$.

13 Roberts M F. Antiinflammation studies. II. Antiinflammatory properties of selenium. Toxicol Appl Pharmacol 1963; 5 : $500-6$.

14 Balansky R M, Argirova R M. Sodium selenite inhibition of the reproduction of some oncogenic RNA-viruses. Experientia 1981; 37: 1194-5.

15 Reffett J K, Spears J W, Brown T T Jr. Effect of dietary selenium on the primary and secondary immune response in calves challenged with infectious bovine rhinotracheitis virus. American Institute of Nutrition 1987: 229-35.

16 Aaseth J, Munthe E T, Forre O, Steinnes E. Trace elements in serum and urine of patients with rheumatoid arthritis. Scand $\mathcal{F}$ Rheumatol 1978; 7: 237-40.

17 Tarp U, Overvad K, Hansen J C, Thorling E B. Low selenium level in severe rheumatoid arthritis. Scand $f$ Rheumatol 1985; 14: 97-101.

18 Arnett F C, Edworthy S M, Bloch D A, et al. The American Rheumatism Association 1987 revised criteria for the classification of rheumatoid arthritis. Arthritis Rheum 1988; 31: 315-24.

19 Blotcky A J, Arsenault L J, Rack E P. Optimum procedure for the determination of selenium in biological specimens using $77 \mathrm{~m}$ Se neutron activation. Anal Chem 1973; 45: $1056-60$.

20 Peretz A, Neve J, Vertongen F, Famaey J P, Molle L. Selenium status in relation to clinical variables and corticosteroid treatment in rheumatoid arthritis. corticosteroid treatment in

21 Sonne M, Jense P T, Helleberg L. Selenium status in patients with rheumatoid arthritis. Scand $\mathcal{F}$ Rheumatol 1985; 14: 318-9.

22 Hochberg M C. Adult and juvenile rheumatoid arthritis: current epidemiologic concepts. Epidemiol Rev 1981; 3: $27-44$.

23 Williams R C, McCarty D J. Clinical picture of rheumatoid arthritis. In: McCarty D J ed. Arthritis and allied conditions. 10th ed. Philadelphia: Lea and Febiger, 1985: 605-19.

24 Tarp U, Overvad K, Thorling E B, Graudal H, Hansen J C. Selenium treatment in rheumatoid arthritis. Scand $\dot{f}$ Rheumatol 1985; 14: 364-8.

25 Tarp U, Hansen J C, Overvad K, Thorling E B, Tarp B D, Graudal $H$. Glutathione peroxidase activity in patients with rheumatoid arthritis and in normal subjects: effects of longterm selenium supplementation. Arthritis Rheum 1987; 30: term selenin.

26 O'Dell J R, McGivern J P, Kay H D, Klassen L W. Improved survival in murine lupus as the result of selenium supplementation. Clin Exp Immunol 1988; 73: 322-7.

27 Parnham M J, Winkelmann I, Leyck S. Macrophage, lymphocyte and chronic inflammatory responses in selenium deficient rodents. Association with decreased glutathione peroxidase activity. Int $\mathcal{f}$ Immunopharmacol 1983; 5: 455.

$28 \mathrm{Li} \mathrm{J}$, Ren S, Chen D. A study of Kashin-Beck disease associated with environmental selenium in Shanxi area. Hunajing Kexue Xuebao 1982; 2: 91-101.

29 Thompson H J, Becci P J. Selenium inhibition of N-methyl$\mathrm{N}$-nitrosurea-induced mammary carcinogenesis in the rat. f Natl Cancer Inst 1980; 65: 1299-301.

30 Harr J R, Exon J H, Weswig P $\mathbf{H}$, et al. Relationship of dietary selenium concentrations, chemical cancer induction and tissue concentration of selenium in rats. Clinical Toxicology 1973; 6: 487-95.

31 Medina D, Shepherd F. Selenium-mediated inhibition of 7,12-dimethylbenz[a]anthracene-induced mouse mammary tumorigenesis. Carcinogenesis 1981; 2: 451-5.

32 Chen X, Yang G, Chen J, Chen X, Wen Z, Ge K. Studies on the relations of selenium and Keshan disease. Biological and the relations of selenium and Keshan disease.

33 Johnson R A, Baker S S, Fallon J T, et al. An occidental case of cardiomyopathy and selenium deficiency. $N$ Engl $\mathcal{J}$ Med 1981; 304: 1210-2 